\title{
EFFECT OF FEEDING ON THE SENSORIAL QUALITY OF LAMB AND GOAT KID MEAT
}

\author{
Elita Aplocina $^{1 *}$, Evita Straumite ${ }^{2}$, Ruta Galoburda ${ }^{2}$, Daina Kairisa ${ }^{1}$ \\ ${ }^{1}$ Institute of Animal Sciences, Faculty of Agriculture, Latvia University of Life Sciences and Technologies, Liela iela 2, \\ Jelgava, Latvia, e-mail: elita.aplocina@llu.lv \\ ${ }^{2}$ Department of Food Technology, Faculty of Food Technology, Latvia University of Life Sciences and Technologies, \\ Rigas iela 22, Jelgava, Latvia
}

\begin{abstract}
Goat kid and lamb meat is quite well accepted by the consumers. The specific flavour is more expressed for sheep meat, also lamb meat has more intense aroma and it is more tender than that of goat kid meat. Several factors can affect the quality characteristics of goat kid and lamb meat, and the feeding of livestock is one of them. The aim of this study was to evaluate the effect of feeding on the lamb and goat kid meat physical and sensorial quality. In the samples of $M$. semimembranosus muscles from 8 Boer goat kids and 8 Latvian Dark head lambs (four animals per treatment) finished on diets varying in content of concentrated feed were analysed for the proximate composition, chemical and physical indices. Four Boer goat kids as feed supplement received oats, four kids - fodder beans, four lambs - a mix with fodder beans, four lambs - a mix with beans and peas. For sensory evaluation as control was used beef meat. For all five samples hardness and intensity of sensory properties (aroma, texture, taste and aftertaste) were analysed. Non-significant ( $>0.05)$ influence was obtained on meat hardness according different additives of concentrated feed. There was no significant difference $(p>0.05)$ in aroma and taste between samples, but there was significant difference in the texture and aftertaste $(p<0.05)$. The aftertaste was weak for beef meat (BM) sample, but there were no significant differences ( $>0.01)$ in the intensity of aftertaste with both goat kid meat samples. However, there was a significant difference $(\mathrm{p}<0.05)$ between both lamb meat samples.
\end{abstract}

Keywords: lamb meat, goat kid meat, quality, sensory properties

\section{Introduction}

Goats and sheep in farmland were kept for centuries and were mainly used for milk, meat and wool production (Zervas et al., 2011). Small ruminants are the most efficient transformers of low-quality forage into high quality animal products (Lombardi, 2005) with distinguished chemical composition and organoleptic characteristics, and with the least use of fossil fuel.

The number of meat goats worldwide totals 464 million heads and meat sheep's - 567 million heads, and the estimated goat meat production is 5.8 million tons, sheep meat - 9.4 million tons (FAO, 2017). However, despite the large number of animals, consumers still prefer beef rather than sheep or goat meat. In Latvia the number of goats for meat production is 4 thousand heads and sheep's - 50.5 thousand heads, and the estimated sheep meat production is 0.9 thousand tons, but no production of goat meat for market (FAO, 2017). According to Teixeira et al. (2017) the most popular is meat from sheep and goats till 3 months of age and 5$8 \mathrm{~kg}$ carcass weight (cordeiro and cabrito) or from sheep and goats with 6 to 9 months age and more than $11 \mathrm{~kg}$ carcass weight (lamb and chivo). Nutritionally, goat is an important source of high-quality proteins, healthy fats, and with low calorie, intramuscular fat, saturated fat, and sodium contents. Besides, goat meat is rich in iron, potassium and essential amino acids, ensuring that goat meat is high quality meat (Horcada et al., 2012). There are two main farming and feeding systems for lamb and goat kid meat production - intensive and extensive, with a great variation between those two (Joy et al., 2008). Feeding forage, which also includes grain feed, can alter carcass quality indices as well as internal and carcass fat levels (Goetch et al., 2011). The proportion of concentrated feed may have a few impacts on meat quality, but the total level of carcass fat was higher among diets higher in concentrates (Ryan et al., 2007). The content of fat in the sheep and goat carcass is very variable. In females fats are deposited in the carcass tissue relatively faster than in males, but in wethers intermediate (Mahgoub et al., 2005). These differences are more pronounced in the case of high levels of energy and concentrates in the feed. Restricted intake of nutrients increases lean meat production and reduces fat accumulation regardless of gender.

In recent years, consumers have been choosing healthier foods and are paying more attention to product quality. It has been found that milk and meat fat and cholesterol content can have a significant impact on human health (Zervas et al., 2011). Meat quality, as perceived by consumers, is a subjective, multidimensional and dynamic concept. Consumers around the world consume both sheep and goat meat, and in some cases can even replace mutton, lamb or beef. Gkarane et al. (2017) reported small sensory differences due to lamb sex. Ram meat has a more intense aroma compared to the castrate meat, more pronounced animal and farm smell, aroma of wool, aroma of manure and sweat. A similar assessment is also given to goat meat. Carcass weight and dressing percentage depends on feeding of lambs and goat kids. Feeding system also can have impact on animal's growth rate, meat quality indices (muscle and fat ratio, content of fatty acids), meat flavours, taste and tenderness, intensity of fat deposition. Carcass dressing percentage, conformation score and fatness degree also depends on feeding of lambs and kids (Carrasco et al., 2009; Toplu et al., 2013).

The quality of meat, which depends on the chemical, microbial and sensorial qualities of the meat, is important for consumers when buying meat (Madruga et al., 2010). In the past, the consumers have encountered a negative experience with the purchase of 
older animal's meat with a pronounced sheep or goat taste and fiberiness. Nowadays, consumers are given the opportunity to buy the meat from young animals (chevon) (Brand et al., 2018), which haven't pronounced specific taste and aroma. Goat kid meat is preferred with less fat than beef or lamb. Therefore, it requires low-heat and slow cooking to preserve tenderness and juiciness (Madruga et al., 2010; Silva et al., 2011).

In recent years, the demand for low-fat meat and meat products has increased in order to avoid health risks associated with excessive fat intake. It is known that goats produce meat with a low fat content. Information on the characteristics of goat and sheep meat and its products in Latvia is still limited and needs more study. The present study attempts to evaluate the effect of feeding on the lamb and goat kid meat physical and sensorial quality.

\section{Materials and Methods}

Meat sampling

Samples of Musculus semimembranosus muscles were taken from 8 Boer goat kids (average age before slaughter 287 days) and 8 Latvian Dark head lambs (average age - 208 days) (four animals per treatment) finished on diets varying in content of concentrated feed. The goat kids and lambs were housed in a barn in four pens. Four Boer goat kids received oats $(\mathrm{G} 1)$ as a feed supplement, four kids - oat mix with fodder beans (G2), four lambs - grains mix with fodder beans (L1), four lambs - grains mix with beans and peas (L2) (Table 1).

Table 1

Scheme of the research

\begin{tabular}{lll}
\hline Groups & $\begin{array}{c}\text { Number } \\
\text { of } \\
\text { animals }\end{array}$ & \multicolumn{1}{c}{ Concentrated feed } \\
\hline G1 & 4 kids & $100 \%$ oats \\
G2 & 4 kids & $\begin{array}{l}85 \% \text { oats }+15 \% \text { fodder beans } \\
15 \% \text { oats }+20 \% \text { barley }+15 \% \text { wheat } \\
+50 \% \text { fodder beans } \\
\text { L1 }\end{array}$ \\
& 4 lambs & $\begin{array}{l}15 \% \text { oats }+20 \% \text { barley }+15 \% \text { wheat } \\
+30 \% \text { fodder beans }+20 \% \text { peas }\end{array}$ \\
\hline L2 & 4 lambs &
\end{tabular}

L1; L2 - lamb meat, G1; G2 - goat kid's meat

The total sample of each kid and lamb group consisted of four samples from each animal left hind leg Musculus semimembranosus, but a sample of beef from M. longissimus was used for comparison. The samples were packed in the thick plastic bags to exclude as much air as possible, and stored at $-20^{\circ} \mathrm{C}$. Before analyses the M. semimembranosus cuts were defrosted at $10^{\circ} \mathrm{C}$ for a period of $24 \mathrm{~h}$.

\section{Physical and chemical analysis}

For raw meat samples content of dry matter, protein, intramuscular-fat was determined using standard analytical methods. Dry matter content was determined by LVS ISO 1442:1997, fat content by LVS ISO 1443:1973, the protein content was calculated from nitrogen content multiplied by 6.25 using ISO 937:1978, pH value by LVS EN ISO 2917:2004.

Moisture-to-protein (W/P) ratio was calculated as an indication of physiological maturity (Brzostowski et al., 2008).

\section{Texture analysis}

A sample of $50 \times 100 \mathrm{~mm}$ was prepared for muscle texture analysis, the longest edge being parallel to the muscle fibres. The sample of $15 \mathrm{~mm}$ thickness was analysed by Warner Bratzler blade (HDP/BSW) on a texture analyser TA.HDplus (Stable Microsystems, UK). Toughness was measured as the maximum force required for shearing a piece of fresh meat perpendicular to the fibre, at a speed of $2 \mathrm{~mm} \mathrm{~s}^{-1}$. Four samples of each goat kid group and two samples from each lamb group were analysed in triplicate for the fibrousness of the muscle tissue. Trigger force was set at $0.098 \mathrm{~N}$. A higher reading indicated a greater shear force and therefore tougher meat.

\section{Sensory analysis}

Meat from two goat kid (samples G1 and G2) and two lamb (samples L1 and L2) groups were sampled to evaluate the sensory properties of the meat, as well as a sample of beef meat from market as a control (BM). Meat samples for sensory evaluation were prepared as meatballs. For the meatballs, to $500 \mathrm{~g}$ of meat one egg was added, the meat was kneaded manually. Meatballs were formed into approximately $3.0 \mathrm{~cm}$ diameter and cooked in water at $90 \pm 5{ }^{\circ} \mathrm{C}$ for $6 \mathrm{~min}$. The cooking process was carried out in two repetitions to ensure that each panellist had a hot, freshly cooked product.

Sensory tests were carried out at the Faculty of Food Technology, Latvia University of Life Sciences and Technologies. A total of 30 semi-trained panellists participated in the evaluation of meat sample sensory attribute intensity and overall liking. The panellists used computers equipped with FIZZ software (Biosystemes, France) to evaluate the intensity of sensory properties (aroma, flavour, texture and aftertaste) on unstructured 7-point line scales (1-weak; 7-very strong). For overall acceptability of meat samples, the ranking test (1-very dislike; 5-like very much) was applied. Between the samples, warm black tea was used for neutralization of taste.

\section{Statistical analysis}

Meat sample chemical composition and sensory properties were analysed with mathematical data processing methods - average, ANOVA. In all analyses, statistical significance was declared at $\mathrm{p}<0.05$.

\section{Results and Discussion}

The quality of the meat is a relative concept and depends on the physical and chemical properties of the meat as well as on the consumer preferences.

\section{Chemical composition and physical attributes of meat}

According to the analyses of Boer goat crossbreed kids and Latvian Dark head lamb meat, was determined an average dry matter (27.0-32.1\%), protein (18.2-19.6\%) 
and intramuscular fat content (6.7-13.9\%) (Table 2). Our results are close to the findings obtained by Moawad et al. (2013) and Dhanda (2001), who reported
$24.7-27.7 \%, 19.9-21.0 \%$ and $3.3-4.7 \%$ for dry matter, protein and fat contents, respectively.

Table 2

Meat quality traits of $M$. semimembranosus muscle of lamb and goat kids

\begin{tabular}{|c|c|c|c|c|}
\hline \multirow{2}{*}{ Parameters } & \multicolumn{4}{|c|}{ Samples } \\
\hline & L1 $(n=4)$ & L2 (n=4) & G1 $(n=4)$ & G2 $(n=4)$ \\
\hline Dry matter, $\%$ & $31.9 \pm 1.04$ & $32.1 \pm 2.27$ & $31.8 \pm 1.28$ & $27.0 \pm 1.06$ \\
\hline Protein, $\%$ & $18.2 \pm 1.16$ & $19.4 \pm 0.64$ & $19.6 \pm 0.53$ & $19.3 \pm 0.26$ \\
\hline Intramuscular fat, $\%$ & $12.05 \pm 0.86$ & $13.9 \pm 1.97$ & $7.9 \pm 0.34$ & $6.7 \pm 1.52$ \\
\hline $\mathrm{pH}$ & $5.71 \pm 0.06$ & $5.69 \pm 0.05$ & $5.77 \pm 0.01$ & $5.87 \pm 0.03$ \\
\hline Moisture / Protein (W / P) ratio & $3.79 \pm 0.26$ & $3.49 \pm 0.08$ & $3.48 \pm 0.04$ & $3.78 \pm 0.08$ \\
\hline
\end{tabular}

L1; L2 - lamb meat, G1; G2 - goat kid's meat

Results of Table 2 indicated that lower dry matter and intramuscular fat content was observed in goat meat samples. These results confirmed the findings obtained by Brzostowski et al. (2008) who reported that goat meat from purebred French Alpine and Boer crossbred kids exhibited a desirable water-to-protein ratios (3.89 and 4.18), respectively. Generally, the lower the water/protein ratio, the better the quality of the meat (Pearson, 1991). In our research adding of fodder beans in feed ration increased the moisture/protein ratio in meat, the meat was with higher content of moisture and lower content of protein.

A key determinant of meat quality is $\mathrm{pH}$. The ultimate $\mathrm{pH}$ values of goat kid's and lamb meat were found as 5.69-5.87 (Table 2), and higher values were found for goat meat. The $\mathrm{pH}$ is important to the chilled meat because it affects its shelf life, colour and quality. High $\mathrm{pH}$ (above 5.8) can indicate stressed animals during preslaughter handling and generally means lower quality of meat, and meat is dark, firm and dry (Dhanda et al., 2003; Hughes et al., 2017). More active animals are easily irritable and thus significantly reduce glycogen reserves in the liver. High $\mathrm{pH}$ in the meat also reflects a decrease in muscle glycogen due to stress or other factors (Muchenje et al., 2009). The lower meat $\mathrm{pH}$ is associated with the tenderness of the meat, which is characterized by longer sarcomeres after cooling and lower shear force value (Simela et al., 2004). However, it is still unclear why goats are so stressed before slaughter.

\section{Meat texture}

Tenderness can be evaluated as the maximum shear force necessary to cut the meat perpendicular to the fibres (Pena et al., 2009).

Table 3

Goat kid and lamb meat tenderness

\begin{tabular}{lcc}
\hline Meat samples & Shear force, $\mathbf{N}$ & $\mathbf{V}, \boldsymbol{\%}$ \\
\hline G1 & $301.90 \pm 34.12$ & 39.15 \\
G2 & $293.50 \pm 17.86$ & 21.07 \\
L1 & $207.00 \pm 7.79$ & 9.22 \\
L2 & $360.10 \pm 42.16$ & 28.68 \\
\hline
\end{tabular}

L1; L2 - lamb meat, G1; G2 - goat kid's meat

$\mathrm{V}$ - coefficient of variation

Average shear force values obtained in this study were from 207 to $360 \mathrm{~N}$ (Table 3) and were much higher to those observed by Moawad et al. (2013) on Egyptian Baladi goat breed goats' kids $\left(58 \mathrm{~N} \mathrm{~cm}^{-2}\right.$ for boiled meat), because our measurements were taken on fresh meat samples. Shear force is highly dependent on the preparation of individual meat samples, temperature, tendon and connective tissue inclusions and other factors, so that the results for each meat sample as well as for the repetition of one sample are not homogeneous. As we can see from the data in Table 3, the most tender meat was obtained from lambs fattened with a higher proportion of fodder beans in the feed, whereas the toughest and most difficult to prepare meat was presented by a lamb group, where the lambs were fed with fodder bean and peas mix. The statistical analysis of the data has shown that there were no significant differences between the groups. According to the research of Johnson et al. (1995), goat meat tenderness was reported to be lower than that of sheep and beef. According to Schenfeldt et al. (1993) study the sheep $M$. semimembranosus was significantly $(\mathrm{p}<0.01)$ more tender than the Angora and Boer goat cuts. In our study for all analysed meat samples we found weak positive correlation $(\mathrm{r}=0.25 ; \mathrm{p}>0.05)$ between fat content and tenderness, but for lamb meat samples we found moderate positive correlation $(\mathrm{r}=0.49 ; \mathrm{p}>0.05)$.

\section{Sensorial attributes of meat}

For five boiled meatball samples (G1, G2, L1, L2 and $\mathrm{BM}$ ) the intensity of sensory properties (aroma, texture, flavour and aftertaste) were analysed.

The taste and flavour of the meat depend on the aldehydes, ketones, sugars, peptides and fatty acids that make up the specific flavour of a species (Madruga et al., 2011).

It has been found that increased intramuscular fat content increases the aroma and flavour of goat meat (Leick et al., 2012). As can be seen from Table 4, there was no significant difference $(p>0.05)$ in aroma and flavour between samples, but there was a significant difference in the samples texture and aftertaste $(\mathrm{p}<0.05)$. In a study completed by Babiker et al. (1990), it was found that goat meat was leaner and darker compared to lamb. A softer, more chewable texture was found for a samples L2 and L1 (lamb) compared to samples G1, G2 (goat kid) and control (BM). 
Intensity of meatballs sensory properties

\begin{tabular}{|c|c|c|c|c|c|}
\hline \multirow{2}{*}{ Attribute } & \multicolumn{5}{|c|}{ Samples } \\
\hline & L1 & L2 & G1 & G2 & BM \\
\hline Aroma & $3.63^{\mathrm{a}}$ & $3.73^{\mathrm{a}}$ & $4.13^{\mathrm{a}}$ & $3.60^{\mathrm{a}}$ & $4.10^{\mathrm{a}}$ \\
\hline Texture & $3.23^{\mathrm{b}}$ & $3.53^{\mathrm{ab}}$ & $4.10^{\mathrm{a}}$ & $4.10^{\mathrm{a}}$ & $4.07^{\mathrm{a}}$ \\
\hline Flavour & $4.33^{\mathrm{a}}$ & $4.17^{\mathrm{a}}$ & $3.90^{\mathrm{a}}$ & $3.87^{\mathrm{a}}$ & $3.80^{\mathrm{a}}$ \\
\hline Aftertaste & $3.77^{\mathrm{a}}$ & $4.10^{\mathrm{a}}$ & $3.70^{b}$ & $3.63^{\mathrm{ab}}$ & $3.17^{\mathrm{b}}$ \\
\hline
\end{tabular}

the same letters in rows indicate no significant differences between samples $(\mathrm{p}<0.05)$

L1; L2 - lamb meat, G1; G2 - goat kid's meat, BM - control, beef meat

The texture of the meat shared a positive strong correlation with meat protein content $(\mathrm{r}=0.81 ; \mathrm{p}<0.05)$, and a strong negative correlation with meat fat content $(\mathrm{r}=-0.88 ; \mathrm{p}<0.05)$ and flavour of the meat $(\mathrm{r}=-0.98$; $\mathrm{p}<0.05)$. A weak aftertaste has been found for a control sample $(\mathrm{BM})$, which was not significantly different $(\mathrm{p}<0.05)$ from the $\mathrm{G} 1$ and $\mathrm{G} 2$ samples. While, the samples G1 and G2 did not differ significantly from the L1 and L2 samples in the aftertaste intensity. In our research we found strong positive correlation with intramuscular fat content and aftertaste $(r=0.77$; $\mathrm{p}<0.05)$. It means that if meat is fattier, it will be more tender, less structured, and with more expressed flavour and aftertaste.

Table 5

Correlation between sensory attributes

\begin{tabular}{lrrrr}
\hline Properties & Aroma & Texture & Flavour & Aftertaste \\
\hline Aroma & 1.00 & & & \\
Texture & 0.56 & 1.00 & & \\
Flavour & -0.59 & -0.98 & 1.00 & \\
Aftertaste & -0.52 & -0.58 & 0.69 & 1.00 \\
\hline
\end{tabular}

In this study we found a strong negative correlation $(\mathrm{r}=-0.98, \mathrm{p}<0.05)$ between meat texture and flavour (Table 5) - the softer is meat texture, the more pronounced the flavour. According to Brand et al. (2018) the goat kid meat flavour showed a moderate correlation with meat aroma $(\mathrm{r}=0.59 ; \mathrm{p}<0.01)$, but in our research meat flavour shown moderate negative correlation with meat aroma $(r=-0.59 ; \mathrm{p}<0.05)$ (Table 5). Also Brand et al. (2018) found that lamb had a more pronounced flavour and aroma, but the goat meat had no such pronounced taste.

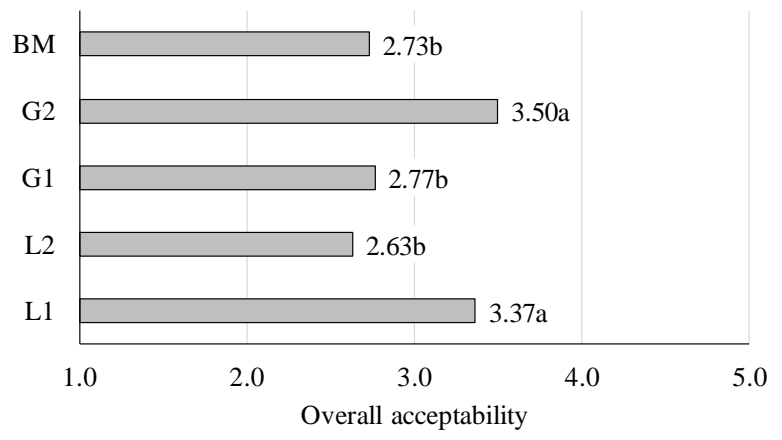

Figure 1. Overall acceptability of meatball samples the same letters indicate no significant differences between samples $(\mathrm{p}<0.05)$

L1; L2 - lamb meat, G1; G2 - goat kid's meat, BM - control, beef meat
One of the most important factors determining the quality of cooked meat is the tenderness of the meat. Similar results were achieved on Boer goats by Werdi Pratiwi et al. (2004), indicating that meat tenderness is an important factor in assessing the sensory properties of meat. Using the Ranking test, the degree of overall acceptability of meatball samples (Figure 1) was determined on the scale: 1-very dislike, 5-like very much.

Panellists more preferred samples L1 and G2, because they liked their texture and taste. For the control sample (BM), the overall acceptability level was the same as for samples L2 and G1. These samples panellists described as difficult to chew with weak taste and flavour. The results obtained suggest that the panellists did not have a negative attitude towards the specific taste and flavour of the samples, as described by the other scientific studies. Low consumption of lamb and sheep meat in European countries (OECD, 2019) is associated with this specific meat taste. Crouse (1983) indicated that consumers prefer beef or pork instead of lamb. The opinions of the panellists as to why the particular meat sample was liked or disliked differed drastically because each person has different preferences of what he likes or dislikes.

Southeast countries consumers prefer sheep meat instead of beef or pork meat, so the market generally lacks both lamb and mutton.

\section{Conclusions}

As indicated by chemical parameters, lower dry matter and intramuscular fat content was observed in goat meat samples. Adding of fodder beans in feed ration increased the moisture/protein ratio in meat; the meat was with higher content of moisture and lower content of protein. More tender meat was obtained from lambs fattened with a higher proportion of fodder beans in the feed, whereas tougher and the most difficult to prepare meat was presented by a lamb group, where the lambs were fed with fodder bean and peas mix. There was no significant difference $(\mathrm{p}>0.05)$ in aroma and flavour between samples, but there was significant difference in the texture and aftertaste $(\mathrm{p}<0.05)$. The aftertaste was weak for beef meat (BM) sample, but there were no significant differences $(p>0.05)$ in the intensity of aftertaste in both goat kid meat samples. The most pronounced aftertaste was in lamb meat samples, and in our research we found strong positive correlation with intramuscular fat content $(r=0.77 ; p<0.05)$. It means that 
if meat is fattier, it will be more tender, less structured, and with more expressed flavour and aftertaste.

By physical properties, as well as eating qualities, it is concluded that goat kids meat from Boer crossbreed raised under Latvian conditions is an excellent source of healthy red meat alternative. The findings suggested that different diets can be varied to still produce chevon and lamb meat with uniform meat quality characteristics.

\section{Acknowledgments}

Financial support for the research project was provided by Latvia Ministry of Agriculture.

\section{References}

1. Babiker S.A., El Khider I.A., Shafie S.A. (1990) Chemical composition and quality attributes of goat meat and lamb. Meat Science, Vol. 28, p. 273-277.

2. Brand T.S., Van Der Merwe D.A., Hoffman L.C., Geldenhuys G. (2018) The effect of dietary energy content on quality characteristics of Boer goat meat. Meat Science, Vol. 139, p. 74-81.

3. Brzostowski H., Niznikowoski R., Tanski Z. (2008) Quality of goat meat from purebred French Alpine kids and Boer crossbreeds. Archiv fur Tierzucht-Archives of Animal Breeding, Vol. 51 (4), p. 381-388.

4. Carrasco S., Ripoll G., Sanz A., Alvarez-Rodriquez J., Panea B., Revilla R., Joy M. (2009) Effect of feeding system on growth and carcass characteristics of Churra Tensina light lambs. Livestock Science, Vol. 121, p. 56-63.

5. Crouse J. D. (1983) The effects of breed, sex, slaughter weight, and age on lamb flavor. Food Technology, Vol. 39, p. 264-268.

6. Dhanda J.S. (2001) Evaluation of crossbred goat genotypes for growth, carcass and meat quality characteristics. Ph.D. Thesis, University of Queensland, Australia.

7. Dhanda J.S., Taylor D.G., Murray P.J. (2003) Growth, carcass and meat quality parameters of male goats: effects of genotype and live weight at slaughter. Small Ruminant Research, Vol. 50, p. 57-66.

8. Food and Agriculture Organization of the United Nations (FAO), 2017. Available: http://www.fao.org/faostat/en/\#data/QL

9. Gkarane V., Allen P., Gravador S., Diskin M.G., Claffey N.A., Fahey A.G., Brunton N.P., Farmer L.J., Moloney A.P., Monahan F. J. (2017) Effect of castration and age at slaughter on sensory perception of lamb meat. Small Ruminant Research, Vol. 157, p. 65-74.

10. Goetsch A.L., Merkel R.C., Gipson T.A. (2011) Factors affecting goat meat production and quality. Small Ruminant Research, Vol. 101, p. 173-181.

11. Horcada A., Ripoll G., Alcalde M. J., Sanudo C., Teixeira A., Panea B. (2012) Fatty acid profile of three adipose depots in seven Spanish breeds of suckling kids. Meat Science, Vol. 92, p. 89-96.

12. Hughes J., Clarke F., Purslow P., Warner R. (2017) High $\mathrm{pH}$ in beef longissimus thoracis reduces muscle fibre transverse shrinkage and light scattering which contributes to the dark colour. Food Research International, Vol. 101, p. 228-238.

13. Johnson D. D., Eastridge J. S., Neubauer D. R., McGowan C.H. (1995) Effect of sex class on nutrient content of meat from young goat. Journal of Animal Science, Vol. 73, p. 296-301.
14. Joy M., Ripoll G., Delfa R. (2008). Effects of feeding system on carcass and non-carcass composition of Churra Tensina light lambs. Small Ruminant Research, Vol. 78, p. 123-133.

15. Leick C., Behrends J., Solaiman S., Broadway P., Min B., Mikel W., Schilling M. (2012) Sensory properties and instrumental texture analysis of chevon patties from intact male Boer and Kiko goats harvested at four endpoints. Meat Science, Vol. 91, p. 215-222.

16. Lombardi G. (2005) Optimum management and quality pastures for sheep and goat in mountain areas. In: Molina Alcaide E., Ben Salem H., Biala K., Morand-Fehr P. (eds.). Sustainable grazing, nutritional utilization and quality of sheep and goat products. Zaragoza: CIHEAM, p. 19-29.

17. Madruga M., $\quad$ Elmore J., Oruna-Concha M., Balagiannis D., Mottram D. (2010) Determination of some water-soluble aroma precursors in goat meat and their enrolment on flavour profile of goat meat. Food Chemistry, Vol. 123, p. 513-520.

18. Madruga M.S., Bressan M. C. (2011) Goat meats: Description, rational use, certification, processing and technological developments. Small Ruminant Research, Vol. 98(1-3), p. 39-45.

19. Mahgoub O., Lu C.D., Hameed M.S., Richie A., Al-Halhali A.S., Annamalai K. (2005) Performance of Omani goats fed diets containing various metabolizable energy densities. Small Ruminant Research, Vol. 58, p. 175-180.

20. Moawad R.K., Mohamed G.F., Ashour M.M.S., Enssaf M., El-Hamzy A. (2013) Chemical composition, quality characteristics and nutritive value of goat kids meat from Egyptian Baladi breed. Journal of Applied Sciences Research, Vol. 9 (8), p. 5048-5059.

21. Muchenje V., Dzama K., Chimonyo M., Strydom P.E., RaatsJ.G. (2009) Relationship between stress responsiveness and meat quality in three cattle breeds. Meat Science, Vol. 81, p. 653-657.

22. OECD (2019) Meat consumption (indicator). doi: 10.1787/fa290fd0-en (Accessed on 22 February 2019)

23. Pearson D. (1991) The Chemical Analysis of Food. Churchill: New York, London, p. 374-410.

24. Pena F., Bonvillani A., Freire B., Juarez M., Perea J., Gomez G. (2009) Effects of genotype and slaughter weight on the meat quality of Criollo Cordobes and Anglonubian kids produced under extensive feeding conditions. Meat Science, Vol. 83, p. 417-422.

25. Ryan S.M., Unruh J.A., Corrigan M.E., Drouillard J.S., Seyfert M. (2007) Effects of concentrate level on carcas traits of Boer crossbred goats. Small Ruminant Research, Vol. 73, p. 67-76.

26. Schenfeldt H.C., Naud R.T., Bok W., van Heerden S.M, Smit R. (1993) Flavour- and tenderness-related quality characteristics of goat and sheep meat. Meat Science, Vol. 34, p. 363-379.

27. Silva T.M., Oliveira R.L., Larissa Pires Barbosa L.P., Garcez Neto A.F., Bagaldo A.R., Duarte Lanna D.P., Alves da Silva M.C., Brito de Jesus I. (2011) Preliminary study on meat quality of goats fed levels of licury oil in the diet. Asian-Aust. Journal of Animal Science, Vol. 24 (8), p. 1112-1119.

28. Simela L., Webb E.C., Frylinck L. (2004) Effect of sex, age, and preslaughter conditioning on $\mathrm{pH}$, temperature, tenderness properties and colour of indigenous South African goats. Journal of Animal Science, Vol. 34, p. 208-211.

29. Teixeira A., Fernandes A., Pereira E., Manuel A., Rodrigues S. (2017) Effect of salting and ripening on the 
physicochemical and sensory quality of goat and sheep cured legs. Meat Science, Vol. 134, p. 163-169.

30. Toplu H.D.O., Goksov E.O., Nazligul A., Kahraman T. (2013) Meat quality characteristics of Turkish indigenous Hair goat kids reared under traditional extensive production system: effects of slaughter age and gender. Journal of Tropical Animal Health and Production, Vol. 45(6), p. 1297-1304.

31. Werdi Pratiwi N.M., Murray P.J., Taylor D.G. (2004) Meat quality of entire and castrated male Boer goats raised under Australian condition and slaughtered at different weights: physical characteristics, shear force values and eating quality profiles. Animal Science, Vol. 79, p. 213-219.

32. Zervas G., Tsiplakou E. (2011) The effect of feeding systems on the characteristics of products from small ruminants. Small Ruminant Research, Vol. 101, p. $140-149$. 